\title{
STRATEGI PENGADAAN DAN PENGAWASAN PEREDARAN BENIH KARET UNGGUL DAN BERMUTU DI MEDAN, PROVINSI SUMATERA UTARA
}

\author{
H. Kusharyono*
}

\begin{abstract}
ABSTRAK
Tujuan penelitian ini adalah mendorong sistem pengadaan bibit karet yang standar, serta pengawasan yang efektif, sehingga petani mudah memperoleh bibit karet unggul, dan membangun sistem dan sinergi antar lembaga untuk mendorong peningkatan produktivitas karet unggul nasional melalui pencegahan peredaran bibit karet tidak bermutu. Metode Analisis pada penelitian ini adalah 1.) Analisis Diskriptif, merupakan metode pengkajian masalah yang dilakukan dengan analisis deskriptif, untuk menggambarkan segenap fakta tertentu secara sistematis berkaitan dengan masalah yang dihadapi oleh petani karet. 2.) Analisis Evaluatif, Dari keragaan data sekunder selama 8 tahun (2005-2011) dengan menggunakan pendekatan analisis ekonometrik serta kelayakan usaha, hal ini dilakukan guna mendapatkan gambaran potensi ekonomi terhadap kerugian yang ditimbulkan bila menggunakan bibit karet yang tidak bermutu. Sebagai dasar pembuatan kebijakan sub sektor perkebunan khusunya benih tanaman karet serta pengawasan peredarannya. Untuk mencegah peredaran bibit karet tidak bermutu, terlebih dahulu perlu dipahami beberapa aspek yang terkait dengan karakteristik bibit karet dan rantai peredarannya, adapun upaya yang dapat dilakukan untuk pencegahan meliputi : bentuk bibit karet yang diperdagangkan, mekanisme peredaran bibit karet, siapa-siapa pelakunya, apa peran dan fungsi lembagalembaga terkait, serta faktor-faktor yang mendorong beredarnya bibit karet tidak bermutu. Adapun hasil penelitian yaitu Untuk mewujudkan bibit karet yang murni dan berkualitas unggul perlu disusun suatu strategi efektifyang secara terpadu dapat memecahkan masalah peredaran bibit karet tidak bermutu. Implementasi strategi dimaksud dilaksanakan berdasarkan prioritas dan bertahap dalam waktu beberapa tahun berdasarkan skala prioritas sebagai berikut ini : 1.) Pembenahan sistem 2.) Pelatihan dan Pembekalan Petugas 3.) Implementasi Undang Undang Perbenihan 4.) Peningkatan Kinerja Pengawasan.
\end{abstract}

Kata Kunci: strategi pengadaan, standar bibit, and kontrol sirkulasi 


\begin{abstract}
The purpose of this study is to encourage the standard procurement system of rubber seedlings, as well as effective supervision, so that farmers are easier to obtain superior rubber seedlings, and building systems and synergy among institutions to drive increased productivity through prevention of rubber seedlings which are not qualified. The analysis method in this research is carried out by using: 1) Descriptive analysis that is an assessment method to describe all the specific facts which are systematically related to the problems faced by rubber farmers. 2.) Evaluative Analysis from the performance of the secondary data for 8 years (2005-2011) by using econometric analysis approach and feasibility, this is done in order to get an overview of the economic potential for losses incurred when using a low quality rubber seedlings as the basis of to create policy in plantation sub-sector especially rubber plant seed and monitoring circulation. To prevent the circulation of rubber seeds which are not qualified, first we need to understand some aspects related to the characteristics of rubber seeds and chain circulation, while efforts should be made for prevention include: the shape of rubber seeds traded, the mechanism of distribution of rubber seedlings, the performer, the role and functions of the institutions concerned, and the factors that drive the circulation of rubber seedlings which are not qualified. The research results aim to realize rubber seedlings which have pure and superior quality necessary to develop an effective strategy that can solve the problem in an integrated manner and the circulation of rubber seedlings which are not qualified. Implementation of the strategy is implemented on a priority basis and gradually in a few years time scale based on the following priorities: 1) Improvement System 2.) Training and Supply Officer 3.) Implementation Act Seed 4.) Improved Performance Monitoring.
\end{abstract}

Keywords: procurement strategy, seed standards, and circulation control

\section{PENDAHULUAN}

Tanaman karet (Hevea brasiliensis) merupakan komoditi penting bagi Indonesia setelah minyak bumi dan gas alam. Tanaman ini menghidupi lebih dari 12 juta jiwa penduduk Indonesia. Dengan areal karet mencapai 3,4 juta ha, menjadikan Indonesia sebagai negara yang areal karetnya terluas di dunia. Akan tetapi produktivitas komoditi ini masih sangat rendah sekitar $700 \mathrm{~kg} / \mathrm{ha} /$ tahun karet kering, jauh di bawah Thailand yang sudah mencapai rata-rata $1.500 \mathrm{~kg} / \mathrm{ha} /$ tahun. Rendahnya produktivitas karet Indonesia tersebut antara lain karena areal karetnya didominasi (83\%) oleh perkebunan karet rakyat yang kondisinya sudah tua dan rusak. Di samping itu, laju peremajaan yang berjalan lambat dan penggunaan bibit yang tidak berkualitas juga menjadi penyebab sulitnya meningkatkan produtivitas karet Indonesia.

Bahantanam (bibit) karet yang bermutu merupakan kunci sukses menuju agribisnis 
karet yang mengahasilkan produktivitas tinggi dan memberikan keuntungan secara berkesinambungan, sehingga dianjurkan untuk menggunakan bibit karet unggul pada setiap peremajaan maupun pembukaan kebun baru. Tindakan pemeliharaan yang optimal sekalipun tidak banyak bermanfaat apabila diimplementasikan kepada tanaman yang berasal dari bibit tidak bermutu. Selain itu, tidak ada sistem eksploitasi yang mampu memberikan hasil tinggi dalam jangka panjang secara konsisten apabila bibit yang digunakan tidak bermutu dan memiliki potensi produksi (genetik) yang rendah. Bibit menjadi sangat penting peranannya karena dampak penggunaan bibit karet yang tidak berkualitas adalah sangat besar. Untuk kasus di Indonesia, perhitungan Suhendry, dkk (2006) menunjukkan bahwa areal karet di Indonesia seluas 775.000 ha yang harus diremajakan menggunakan bibit karet asalan yang mengandung bahan genetis asalan, maka potensi kerugian mencapai Rp. 18 triliun dan jika bibit asalan yang digunakan tidak jelas klonnya serta pertumbuhan fisiknya jelek, maka potensi kerugian meningkat mencapai Rp. 30 triliun. Oleh karena itu penggunaan bibit karet asalan atau bibit tidak bermutu harus dihindarkan. Besarnya minat petani pekebun untuk meremajakan /mengembangkan kebun karetnya seiring dengan semakin membaiknya harga karet, menyebabkan meningkatnya kebutuhan terhadap bibit karet di Indonesia. Berdasarkan prediksi yang dikemukakan Direktorat Jenderal Perkebunan tahun 2006, bahwa kebutuhan bibit karet tahun 2006 -
$2008: 31-40$ juta bibit per tahun. Namun produsen bibit yang mampu menghasilkan bibit karet bermutu seperti Pusat Penelitian Karet beserta Balai-Balainya memiliki kapasitas produksi yang terbatas, yaitu hanya sekitar 3 juta batang pertahun. Kesenjangan antara produksi dan kebutuhan bibit karet tersebut merupakan peluang bisnis yang sangat menggiurkan, bagi para penangkar maupun bagi sumber benih/pengusaha perbenihan tanaman perkebunan. Banyaknya bermunculan penangkar bibit karet di satu sisi merupakan kabar baik karena dapat mendukung penyediaan bibit karet dalam jumlah yang demikianbesar, namun di sisi yang lain juga menimbulkan kekhawatiransebab akan banyak pula ditemukan dan digunakan bibit karet dengan kualitas rendah atau yang lebih dikenal dengan bibit karet asalan. Penggunaan bibit karet asalan dalam jangka panjang akan mengakibatkan kerugian yang cukup besar dan menyebabkan produktivitas karet nasional tidak akan mampu ditingkatkan.

Mengingat begitu pentingnya peran bibit unggul dalam agribisnis karet dan sangat besarnya kerugian yang ditimbulkan akibat rendahnya produktivitas tanaman, maka perlu disusun strategi dan mekanisme pengadaan bibit karet serta pengawasan atas peredaran bibit karet tidak bermutu di tengah-tengah masyarakat. Untuk mewujudkan hal tersebut perlu dilakukan penguatan-penguatan kepada petugas pengendali pengawas benih anaman (PBT) perkebunan, termasuk para penangkar bibit. Sosialisasi kepada petani karet mengenai penggunaan bibit karet unggul oleh 
penyuluh/petugas Dinas Perkebunan perlu ditingkatkan.

Tujuan dari penelitian ini adalah mendorong sistem pengadaan bibit karet yang standar, serta pengawasan yang efektif, sehingga petani mudah memperoleh bibit karet unggul, dan membangun sistem dan sinergi antar lembaga untuk mendorong peningkatan produktivitas karet unggul nasional melalui pencegahan peredaran bibit karet tidak bermutu.

\section{METODE PENELITIAN}

\section{Waktu dan Tempat}

Kajian (desk study) ini dilakukan pada bulan Nopember 2012 di Balai Besar Perbenihan dan Proteksi Tanaman Perkebunan (BBP2TP) Medan, Propinsi Sumatera Utara.

\section{Metode Analisis}

\section{a. Analisis Diskriptif}

Metode Pengkajian masalah ini dilakukan dengan analisis deskriptif, untuk menggambarkan segenap fakta tertentu secara sistematis berkaitan dengan masalah yang dihadapi oleh petani karet.

b. Analisis Evaluatif

Dari keragaan data sekunder selama 8 tahun (2005-2011) dengan menggunakan pendekatan analisis ekonometrik serta kelayakan usaha, hal ini dilakukan guna mendapatkan gambaran potensi ekonomi terhadap kerugian yang ditimbulkan bila menggunakan bibit karet yang tidak bermutu. Sebagai dasar pembuatan kebijakan sub sektor perkebunan khusunya benih tanaman karet serta pengawasan peredarannya.

\section{HASIL DAN PEMBAHASAN}

Untuk mencegah peredaran bibit karet tidak bermutu, terlebih dahulu perlu dipahami beberapa aspek yang terkait dengan karakteristik bibit karet dan rantai peredarannya, yang meliputi: bentuk bibit karet yang diperdagangkan, mekanisme peredaran bibit karet, siapa-siapa pelakunya, apa peran dan fungsi lembagalembaga terkait, serta faktor-faktor yang mendorong beredarnya bibit karet tidak bermutu.

1. Bahan Tanam (Bibit) Karet

Bibit bermutu haruslah secara fisik memenuhi ukuran pertumbuhan yang normal, secara fisiologis memiliki daya hidup yang baik, dan secara genetis terdiri dari klon yang asli dan murni. Namun sebaliknya, potensi keunggulan bibit bermutu yang memenuhi syarat fisik, fisiologis, dangen etis tersebut tetap tidak dapat diekspresikan apabila tindakan kultur teknis di lapangan tidak dilakukan secara optimal, dan sistem eksploitasi yang diterapkan tidak sesuai dengan karakteristik klon. Bibit karet bermutu sebenarnya tidaklah sulit untuk dihasilkan, dengan menguasai teknik okulasi, hampir semua orang dapat menghasilkan bibit karet bermutu apabila batang bawah telah memenuhi persyaratan agronomis dan fisiologis, serta tersedianya mata okulasi dari sumber koleksi (kebun entres) yang dapat dijamin keaslian dan kemurnian material genetiknya. 
Bibit karet siap tanam atau yang lebih dikenal sebagai bibit polibeg berpayung 1 daun atau 2 daun berasal dari dua komponen utama, yaitu biji yang akan menjadi batang bawah dan entres yang akan menjadi batang atas tempat produksi lateks diambil. Penurunan kualitas bibit yang dihasilkan ditentukan oleh kedua komponen tersebut. Proses penyuapan bibit karet klonal seperti disajikan pada Gambar 1.

\subsection{Biji Karet}

Jika biji yang dipergunakan tidak terseleksi dengan baik (tingkat kemurnian tinggi dan berasal dari klon anjuran), maka akan dihasilkan suatu pertanaman semaian yang heterogen. Selain tingkat keseragaman yang tinggi, pemeliharaan yang rendah juga akan semakin menurunkan kualitas fisik dan fisiologis semaian batang bawah. Oleh karena itu, biji yang dipergunakan untuk batang bawah harus berasal dari pohon induk yang memenuhi syarat dan telah terseleksi dengan baik.Namun demikian, meskipun sudah diseleksi dengan baik, biji karet tidak dianjurkan dipergunakan sebagai bahan tanaman produksi.

\subsection{Kayu Entres}

Komponen kedua dalam penyiapan bibit karet adalah mata entres yang sering menjadi penyebab dihasilkannya bibit karet tidak bermutu. Oleh karena harga kayu entres yang mahal dan tingginya biaya pembangunan kebun entres, penangkar cenderung mempergunakan mata entres yang

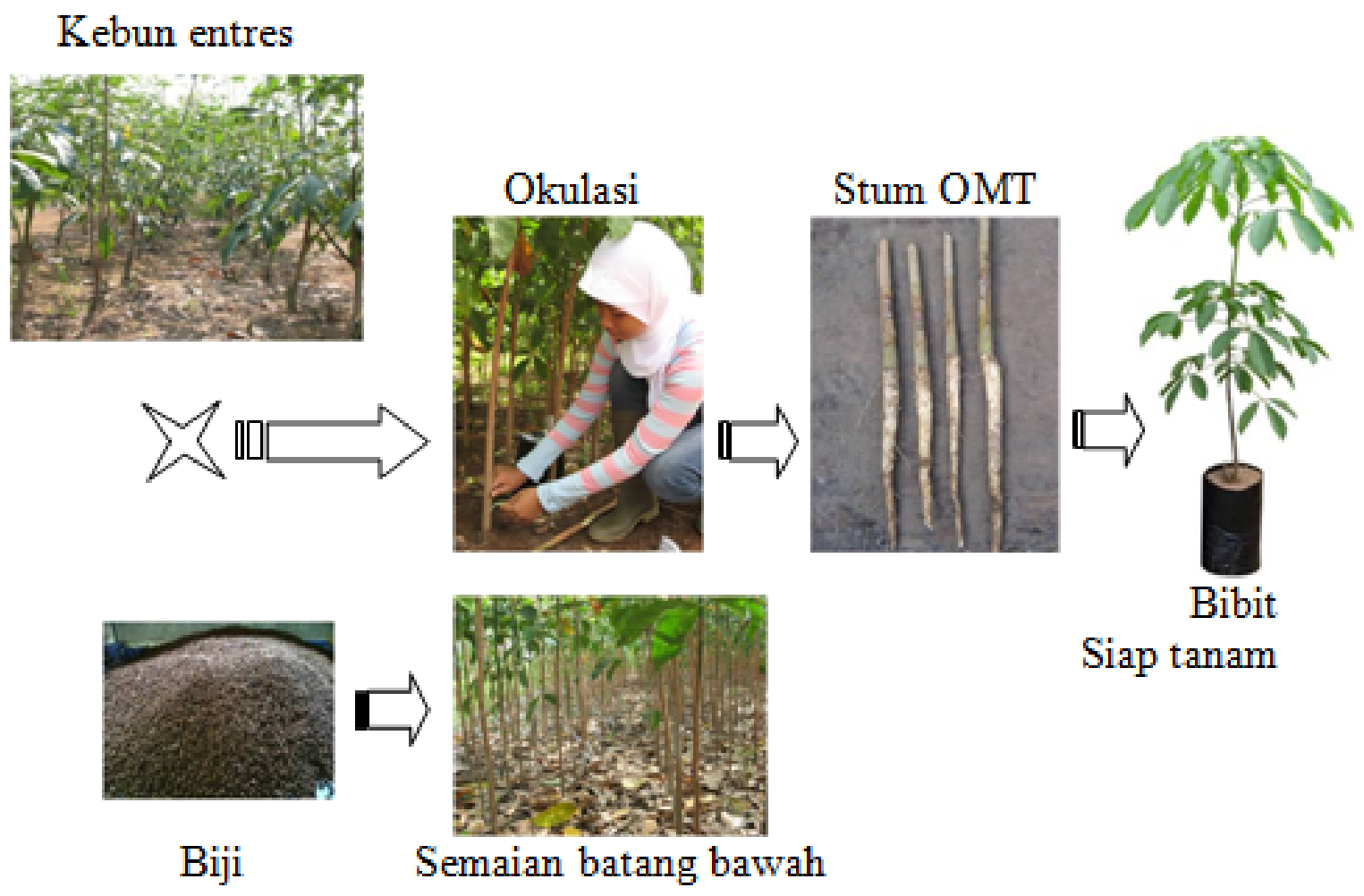

Gambar 1. Proses penyiapan bibit karet melalui teknik okulasi 
berasal dari kebun produksi (takent). Karena sifat juvenilitas takent yang telah berkurang menyebabkan kualitas genetik dari bibit yang dihasilkan juga akan menurun. Manipulasi atas penggunaan jenis mata dan sumber mata entres paling sering terjadi pada tahapan okulasi, antara lain : penggunaan mata sisik, pemakaian mata dari batang bawah itu sendiri (terjun payung) atau mata tunas dari pohon tetangga, tanaman produksi asal seedling, cabang plagiotrop tanaman produksi klonal, atau kebun entres tua dan tidak murni. Kesemua sumber mata entres tersebut akan menghasilkan bibit yang memiliki kualitas genetik (pertumbuhan dan produksi) yang rendah.

\subsection{Stum OMT}

Setelah mata entres diokulasi ke batang bawah sekitar 3-4 minggu, akan dihasilkan bibit karet yang dikenal dengan sebutan stum Okulasi Mata Tidur (stum OMT). Bibit dalam stadia stum belum dianjurkan untuk langsung ditanam ke lapangan karena resiko kematian yang tinggi dan tingkat ketidakseragaman pertanaman yang tinggi. Akan tetapi stadia bibit ini yang paling banyak diperdagangkan karena pertimbangan mobilisasinya yang lebih mudah dan lebih murah di bandingkan bibit polibeg. Kerawanan peredaran justru terjadi pada stadia stum OMT. Hal ini karena dalam stadia stum, tanaman belum memiliki daun,sehingga belum dapat diidentifikasi klonnya.

Didalam transaksi perdagangan stum OMT, kesepakatan antara penjual-pembeli hanya di dasarkan kepada syarat mutu yang sifatnya kualitatif sebagai berikut :

Klon :

- Asli (sesuai sifat genetik)

- Murni (tidak tercampur)

Fisik Bibit :

- Batang sehat

- Diameter batang 1,3-3,0 cm

- Bebas jamur akar putih (JAP)

- Akar tidak bercabang, panjang 25$30 \mathrm{~cm}$

- Mata daun

- Okulasi cukup matang

- Maksimal 2 kali okulasi

Pada saat seleksi stum OMT, hanya karakteristik fisik saja yang dapat diidentifikasi, sedangkan keaslian klon dan kemurnian party bibit tidak akan dapat diketahui. Belum ada teknologi yang dapat mengidentifikasi klon karet ketika masih berupa stum OMT.

\subsection{Bibit Polibeg}

Stum OMT harus terlebih dahulu ditanam ke dalam polibeg hingga memiliki 2 (dua) payung daun sebelum menjadi bibit siap tanam ke lapangan.Pada stadia ini ciri-ciri klon sudah dapat dikenali oleh petugas terlatih. Transaksi dalam stadia bibit polibeg jarang terjadi karena daya angkut yang sedikit dan ongkos yang mahal. Untuk meningkatkan daya angkut ini, penangkar sering sekali memodifikasi ukuran polibeg menjadi lebih kecil $(15 \times 35 \mathrm{~cm})$ dibanding ukuran standar $(20 \times 40 \mathrm{~cm})$. Akibat dari tindakan ini menyebabkan bibit menjadi 
tidak memenuhi syarat mutu karena umumnya akan menggunakan akar yang pendek $(15-20 \mathrm{~cm})$. Adakalanya teknik tersebut untuk menyembunyikan stum berakar pendek yang dihasilkan dari pembibitan.

\section{Rantai Peredaran Bibit Karet}

Klon merupakan hasil perakitan dan seleksi yang dilakukan secara intensif oleh Pusat Penelitian Karet. Untuk tujuan duplikasi, pohon induk klon unggul tersebut diperbanyak dan ditanam pada kebun entres. Melalui kebun entres tersebut, klonklon anjuran selanjutnya menyebar ke berbagai pertanaman komersial. Sampainya klon karet unggul ke petani melalui beberapa rantai peredaran seperti terlihat pada Gambar 2.

\subsection{Penangkar Bibit}

Pusat Penelitian Karet dan Balai Penelitian di Sungai Putih sebagai penemu dan pemilik klon unggul juga berperan sebagai produsen/penangkar yang menjual bibitnya, baik untuk tanaman komersial atau sumber material kebun entres di tempat lain. Produsen bibit skala besar umumnya memiliki kebun entres sendiri, tetapi sebahagian besar penangkar bibit karet (penangkar skala kecil) tidak memiliki kebun entres sendiri karena keterbatasan lahan dan modal. Jika pun ada umumnya dengan luasan yang tidak terlalu besar.
Entres yang mereka pergunakan sebahagian besar berasal dari pertanaman komersil yang dikenal sebagai tak entres. Mata entres dari tak entres tersebut telah diketahui jelek kualitas genetiknya. Bibit yang diproduksi oleh para produsen/ penangkar tersebut dibeli oleh petani/pekebun, agen bibit, atau pesanan proyek-proyek pengembangan karet rakyat.

\subsection{Agen Bibit}

Di dalam rantai peredaran bibit karet juga ada perorangan yang tidak memproduksi bibit, tetapi berperan di dalam mata rantai perdagangan bibit. Ada juga penangkar kecil yang sekaligus berperan sebagai agan bibit untuk melayani pesanan dalam jumlah besar yang tidak dapat dipenuhi dari pembibitannya. Untuk memenuhi permintaan, mereka mengumpulkan bibit dari berbegai panangkar kecil. Akibatnya bibit yang dijual kondisinya sangat beragam karena berbeda pengelolaannya di tingkat penangkar. Bibit yang beragam tidak memenuhi syarat mutu bibit yang harus asli dan murni.Pembeli yang dilayani agen bibit tersebut umumnya adalah petani atau rekanan proyek.

\subsection{Rekanan Proyek}

Disamping agen bibit, pemain di dalam rantai peredaran bibit karet adalah rekanan proyek yang membutuhkan 


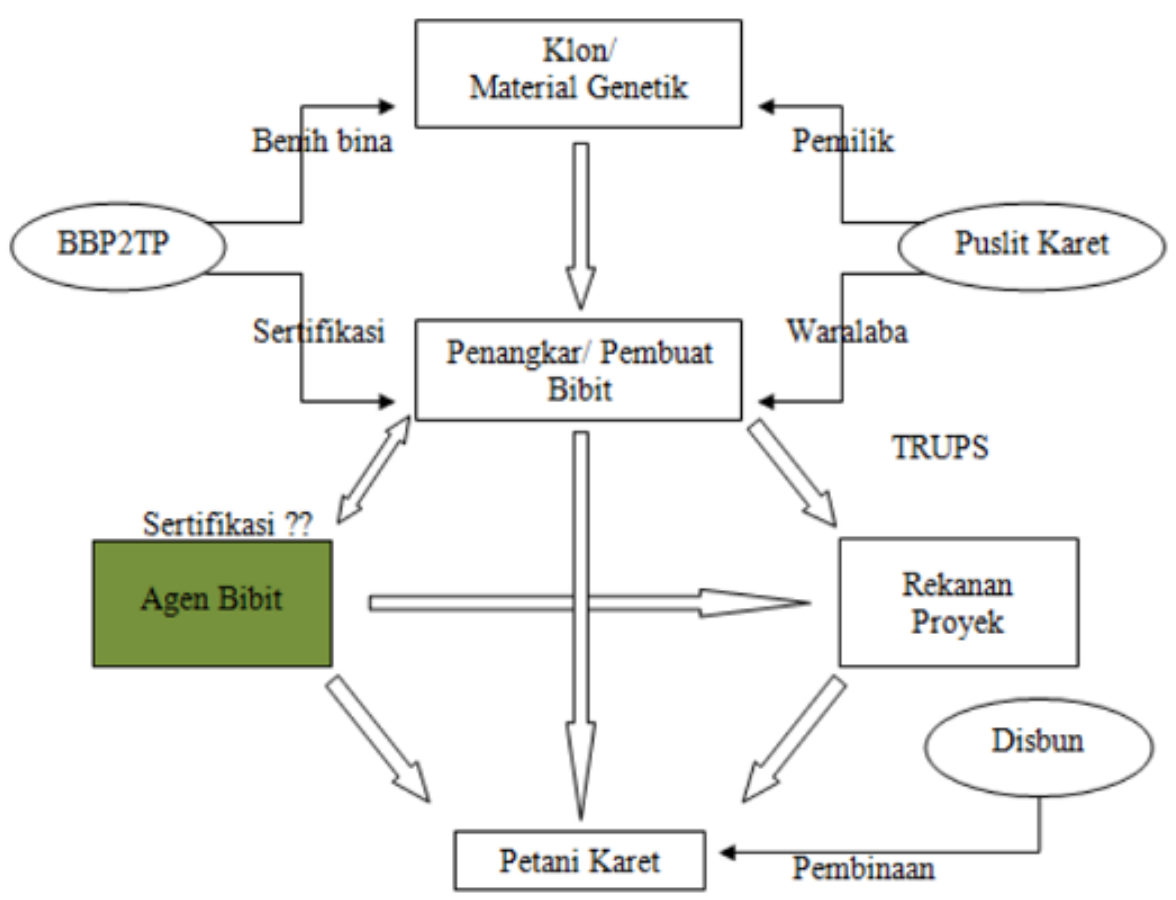

Gambar 2. Rantai peredaran bibit karet hingga ke pertamanan komersial

bibit dalam jumlah besar. Sering sekali karena keterbatasan waktu penutupan proyek (akhir Desember) para rekanan tersebut terpaksa mengumpulkan bibit yang dipesan proyek dari berbagai sumber, termasuk dari penangkar kecil atau agenagen bibit. Jarang sekali mereka memperoleh bibit dari produsen besar yang profesional karena sistem pesanan yang harus dilakukan jauh sebelumnya. Seperti diketahui bahwa bibit karet dipersiapkan sejak musim biji jatuh, bulan NopemberDesember tahun sebelumnya. Produsen bibit besar membuat rencana pembangunan pembibitan berdasarkan estimasi kebutuhan yang dapat diperkirakan karena resiko investasi yang cukup besar, sehingga dibutuhkan adanya kontrak sebelum persemaian biji dimulai. Di sisi lain, tidak ada rekanan yang berani menandatangani kontrak sebelum mereka ditunjuk sebagai pemenang tender, sedangkan pemenang tender baru diketahui sekitar bulan Juni s/d September tahun berikutnya. Akibatnya rekanan hanya memiliki waktu $4-6$ bulan untuk memenuhi pesanan bibit dalam jumlah besar. Hal tersebut menjadi faktor pembatas bagi rekanan untuk mendapatkan bibit yang dipersiapkan secara standar.

\subsection{Petani sebagai Konsumen Bibit}

Pihak yang paling akhir dalam rantai peredaran bibit adalah para petani. Dengan keterbatasan pengetahuan dan dana, petani cenderung masih mempergunakan seedling di kebun karetnya atau membeli bibit karet sembarangan yang murah harganya dari para agen bibit. Adakalanya petani memperoleh bantuan bibit dari dinas perkebunan setempat dalam proyek pengembangan karet rakyat. Petani yang 
datang membeli bibit ke produsen benih standar umumnya adalah petani yang telah berpengetahuan lebih maju.

\section{Peran Lembaga-Lembaga Terkait}

Pada rantai peredaran bibit karet, tidak hanya produsen dan konsumen yang terlibat langsung di dalamnya. Undang-undang telah mengatur peran dan fungsi beberapa lembaga yang dapat mencegah beredarnya bibit karet tidak bermutu di dalam masyarakat.

\subsection{Pusat Penelitian / Balai Penelitian} Sungai Putih

Sebagai penemu dan pemilik varitas lembaga ini dilindungi oleh UU PVT No. 29 Tahun 2002 tentang perlindungan \& insentif penemuan varietas. Dengan UU ini Balai Penelitian Sungai Putih seharusnya memiliki interaksi yang kuat dengan para penangkar bibit karet dalam hal komersialisasi klon-klon karet miliknya. Di samping perlindungan hak tersebut, sebagai pemilik varitas Balai Penelitian Sungai Putih juga memproduksi bibit karet standar dalam jumlah terbatas. Sebagai lembaga penelitian, juga memiliki kemampuan dan teknologi untuk memproduksi bibit karet bermutu yang dapat diimplementasi- kan oleh penangkar bibit lainnya.

3.2. Balai Besar Perbenihan dan Proteksi Tanaman Perkebunan - Medan

Balai Besar Perbenihan dan Proteksi Tanaman Perkebunan (BBP2TP) Medan, merupakan lembaga yang diberi kewenangan dalam pengawasan peredaran benih sesuai dengan amanat di dalam UU Budidaya Tanaman No. 12 Tahun 1992, PP
No 44, dan Peraturan Menteri Pertanian No. 39. BBP2TP mengemban tugas melaksanakan pengawasan dan sertifikasi benih-benih yang beredar di wilayah binaannya, sehingga diharapkan benihbenih yang beredar di masyarakat dapat terjamin mutunya.

Di dalam rantai peredaran bibit karet, BBP2TP selalu berinteraksi dan berkoordinasi dengan Balai penelitian untuk memantau perkembangan terbaru mengenai klon dan teknologi multiflikasinya, melaksanakan pemurnian kebun entres, atau menyelenggarakan pelatihan petugas teknis. Interaksi yang paling entensif adalah dengan para penangkar bibit untuk menilai, mengevaluasi, mengawasi setiap bibit yang dihasilkan oleh penangkar, serta mengeluarkan sertifikasi terhadap setiap bentuk dan individu bibit yang beredar di masyarakat.

\subsection{Dinas Perkebunan}

Di dalam rantai peredaran bibit karet, Dinas Perkebunan setempat memiliki peran yang lebih luas dibandingkan kedua lembaga lainnya. Disamping sebagai pembina petani karet untuk dapat menghasilkan kebun yang memiliki produktivitas tinggi, Dinas juga diberi kewenangan untuk mengeluarkan izin penangkaran bibit (TRUP). Pada program pengembangan karet rakyat bahkan Dinas Perkebunan dapat berperan sebagai konsumen bibit melalui rekanan yang ditunjuknya. 
4. Pemicu Beredarnya Bibit Karet Tidak Bermutu

Dari bentuk (stadia) bahan tanam karet yang diperdagangkan dan rantai peredaran bibit di lapangan seperti yang telah diuraikan di atas, ternyata di lapangan masih banyak terjadinya peredaran bibit karet yang tidak bermutu. Banyak faktor yang telah teridientifikasi sebagai pemicu maraknya peredaran bibit karet tidak bermutu, antara lain :

Teknik perbanyakan yang mudah, dengan memiliki keterampilan melakukan okulasi hampir setiap orang dapat menghasilkan bibit karet.

Sulitnya pembuktian genetis, secara visual keaslian dan kualitas genetis dari bibit karet terutama dalam stadia stum OMT tidak dapat diketahui. Sampai saat ini pembuktian genetis di laboratorium melalui pendekatan molekuler masih berbiaya mahal dan butuh waktu lama.

Kemampuan mendeteksi keaslian dan kemurnian klon yang rendah, dalam peraktek di lapangan belum tersedia metode, prosedur, dan peralatan yang dapat mendeteksi klon secara cepat dan akurat.

\section{Kesenjangan suplay-demand,} permintaan yang sangat tinggi dan persediaan bibit kualitas yang sangat terbatas, mendorong banyak penangkar baru memproduksi bibit karet meskipun tanpa memiliki pengetahuan dan teknologi pembibitan yang belum memadai.

Gap harga dan adanya pembeli, penyiapan bibit karet yang memenuhi standar mutu membutuhkan biaya yang lebih tinggi, sehingga wajar bila terjadi disparitas harga antara bibit standar dengan bibit tidak berkualitas. Perbedaan tersebut terjadi pada ongkos produksi seperti : penggunaan tak ent, biaya upah, olah tanah secara manual, seleksi biji dan bibit yang longgar, serta pemeliharaan bibit yang tidak optimal. Disamping adanya gap harga tersebut, maraknya peredaran bibit tidak berkualitas juga didorong oleh masih banyaknya pembeli (terutama dari kalangan proyek) bibit karet.

Sistem anggaran 1 tahun, proses penyiapan bibit karet yang lebih satu tahun dan sistem anggaran yang harus selesai dalam satu tahun menyulitkan pembeli dalam partai besar memperoleh bibit berkualitas. Hal tersebut karena perencanaan pembangunan pembibitan disusun sebelum proyeks disetujui, sehingga tidak ada rekanan yang bersedia menandatangani kontrak sebelum penyemaian biji sebelum ditunjuk sebagai pemenang tender.

Pengawasan dan pengawalan terhadap penangkar yang belum optimal, sistem pengawasan dan sertifikasi bibit karet lebih cenderung berbasis administratif, bukan proses memproduksi bibit. Hal tersebut dapat difahami mengingat keterbatasan biaya operasional yang dimiliki oleh dinas terkait.

\section{Keterbatasan}

pengetahuanpetani/konsumenmengenaimut ubenih, faktor penting lain yang juga menjadipendorong masih sangat banyaknya peredaran bibit tidak bermutu adalah karena tingkat pengetahuan petani mengenai bibit bermutu yang masih rendah. Bagi petani, yang namanya pohon karet akan tetap 
menghasilkan getah. Petani cenderung lebih suka punya kebun luas meskipun menggunakan bibit murah, daripada membangun kebun kecil dengan kualitas dan produktivitas yang jauh lebih tinggi.

\section{KESIMPULAN DA N SARAN}

\section{Kesimpulan}

1. Untuk mewujudkan bibit karet yang murni dan berkualitas unggul perlu disusun suatu strategi efektif yang secara terpadu dapat memecahkan masalah peredaran bibit karet tidak bermutu.

2. Implementasi strategi dimaksud dilaksanakan berdasarkan prioritas dan bertahap dalam waktu beberapa tahun berdasarkan skala prioritas 1) Pembenahan sistem 2) Pelatihan dan Pembekalan Petugas 3) Implementasi Undang Undang Perbenihan 3) Peningkatan Kinerja Pengawasan.

\section{Saran}

1. Implementasi program strategis dilaksanakan dengan perencanaan dan operasional yang efektif, terpadu dan bertahap melalui program khusus berupa gerakan secara nasional untuk komoditi karet.
2. Direktorat Jenderal Perkebunan melalui Direktorat Tanaman Tahunan perlu melibatkan secara aktif lembaga terkait: BBP2TP Medan, Balai Penelitian Karet dan Dinas Perkebunan.

\section{DAFTAR PUSTAKA}

Badan Penelitian dan Pengembangan Pertanian, Departemen Pertanian, 2005. "Prospek dan arah pengembangan agribisnis karet". Jakarta : Badan Litbang Pertanian.

Balai Penelitian Sungai Putih, 2008.

"Bahan Tanaman Klon Karet Unggul" Galang - Deli Serdang.

Direktorat Jenderal Perkebunan, 2006. "Road Map Komoditi Karet 2005-2025". Jakarta: Ditjenbun.

Direktorat Jenderal Perkebunan, 2012.

"Peningkatan Produksi,

Produktivitas dan Mutu Tanaman

Tahunan, Pedoman Teknis Peremajaan Tanaman Karet”. Jakarta: Ditjenbun.

Pusat Penelitian Karet, 2009. "Prosiding

Lokakarya Nasional Pemuliaan Tanaman Karet". Batam: 4-6 Agustus 2009.

\footnotetext{
* Kepala BВР2TP Medan
} 
